\title{
ELECTROLESS AMORPHOUS ALLOY ELECTRODES-THE FORMATION AND PROPERTIES OF HYDROUS OXIDE COATINGS IN ALKALINE SOLUTION
}

\author{
T. Kessler, ${ }^{*}$ J. J. Podestá, $\nmid$ R. C. V. Piatti, $†$ W. E. Triaca $\dagger$ and A. J. Arvia $\dagger$ \\ * Facultad de Ingeniería, Universidad Nacional del Centro de la Provincia de Buenos Aires, Casilla de \\ Correo 12, 7400 Olavarria, Argentina \\ †Instituto de Investigaciones Fisicoquímicas Teóricas y Aplicadas (INIFTA), Facultad de Ciencias \\ Exactas, Universidad Nacional de La Plata, Sucursal 4, Casilla de Correo 16, 1900 La Plata, Argentina
}

(Received 13 September 1993; accepted 17 December 1993)

\begin{abstract}
Amorphous alloys $\left(\mathrm{Co}_{94.6} \mathrm{P}_{3.4}\right.$ and $\left.\mathrm{Co}_{71.6} \mathrm{Ni}_{18.3} \mathrm{P}_{10.1}\right)$ were prepared by the electroless technique. Oxide coated amorphous alloys were produced by applying a cyclic potential routine to the amorphous alloys immersed in alkaline solution at $30^{\circ} \mathrm{C}$. Oxide coatings were characterized by electrochemical techniques and ir spectroscopy. The electrocatalytic activity of oxide coated amorphous alloy electrodes was tested for the oxygen evolution reaction in alkaline solution at $30^{\circ} \mathrm{C}$. The high electrocatalytic activity of these electrodes is explained through the development of a porous hydrous oxide film with a spinel-type structure.
\end{abstract}

Key words: amorphous alloy, electroless deposition, oxide coating, spinel structures, oxygen evolution reaction.

\section{INTRODUCTION}

Amorphous alloys are promising low cost electrocatalysts for water electrolysis in alkaline solutions[1-3]. Among several methods, electroless deposition appears as a relatively easy way for tailoring desired amorphous alloy compositions on either conductor or insulator materials [4-6].

Hydrous oxide coatings of controlled thicknesses can be easily grown by applying cyclic potential routines to either metals or amorphous alloys immersed in aqueous solution[7-12]. For $\mathrm{Co}-\mathrm{Ni}$ amorphous alloys, hydrous oxide films which are precursors of spinel-structures have been obtained[12]. This type of oxide coated electrodes exhibits a high electrocatalytic activity towards the oxygen evolution reaction (oer) in alkaline solution [13].

This work describes the optimal conditions for the preparation of hydrous oxide coatings on electrolessprepared $\mathrm{Co}_{94.6} \mathrm{P}_{5.4}$ and $\mathrm{Co}_{71.6} \mathrm{Ni}_{18.3} \mathrm{P}_{10.1}$ electrodes by applying a square wave potential routine (SWPR) in alkaline solution, and their characterization.

\section{EXPERIMENTAL}

The working electrodes (we) consisted of an amorphous alloy of about $20 \mu \mathrm{m}$ in thickness which was electroless-deposited on standard $\mathrm{Al}_{2} \mathrm{O}_{3}$ wafers as described elsewhere[6]. Amorphous alloy compositions in atg $\%$ were represented by the following stoichiometric formula, $\mathrm{Co}_{94.6} \mathrm{P}_{5.4}$ and $\mathrm{Co}_{71.6} \mathrm{Ni}_{18.3} \mathrm{P}_{10.1}[6]$.
Runs were made in a conventional three-electrode glass cell in $1 \mathrm{M} \mathrm{NaOH}$ at $30^{\circ} \mathrm{C}$ under $\mathrm{N}_{2}$ saturation. A large Pt foil counter electrode (ca. $10 \mathrm{~cm}^{2}$ ) and a reversible hydrogen reference electrode (rhe) in the same solution were used.

The we were potential cycled at $0.1 \mathrm{Vs}^{-1}$ between 0.30 and $1.55 \mathrm{~V}$ for $10 \mathrm{~min}$ and then subjected to the SWPR treatment to produce an oxide coating. The SWPR parameters covered the following ranges: $0 \leqslant E_{\mathrm{u}} \leqslant 2 \mathrm{~V} ; \quad-2 \leqslant E_{1} \leqslant 0 \mathrm{~V} ; \quad 0.025 \leqslant f \leqslant 5 \mathrm{kHz} ;$ $5 \leqslant t \leqslant 120 \mathrm{~s}$, where $E_{\mathrm{u}}$ and $E_{1}$ are the anodic and cathodic switching potentials, respectively; $f$ and $t$ are the frequency and the duration of the SWPR treatment, respectively. SWPR treatments under the above mentioned conditions provided amorphous alloy electrode surfaces without traces of $\mathrm{Pt}$, at least as revealed by XPS analysis[12]. It should be noted that for the optimal value of $f$, ie $f=0.1 \mathrm{kHz}$, in alkaline solutions, no $\mathrm{Pt}$ electrodissolution could be detected, in contrast to results obtained in acid solutions at lower values of $f[14,15]$. Occasionally, the oxide coated we were further treated at $380^{\circ} \mathrm{C}$ under $\mathrm{N}_{2}$ atmosphere. Then, three types of we were used, namely, untreated (type I), oxide coated (type II) and thermally treated oxide coated (type III) electrodes.

The relative increase in the amount of oxide accumulated on the we was evaluated through the ratio, $R=Q_{\mathrm{a}} / Q_{\mathrm{b}}$, where $Q_{\mathrm{b}}$ and $Q_{\mathrm{a}}$ are the overall voltammetric charge obtained from the stabilized voltammogram at $0.1 \mathrm{~V} \mathrm{~s}^{-1}$, before and after the above mentioned treatments, respectively.

Quasi-steady-state polarization curves for the oer were determined at $10^{-4} \mathrm{Vs}^{-1}$. The current density (j) was referred to the we geometric area $\left(1 \mathrm{~cm}^{2}\right)$. 
Electrochemical data were complemented with ir spectra of powdered metal oxide coatings.

\section{RESULTS}

Stabilized voltammograms run at $0.1 \mathrm{Vs}^{-1}$ between 0.30 and $1.55 \mathrm{~V}$ for Co-P amorphous alloys before and after the SWPR treatment $\left(E_{\mathrm{u}}=1.6 \mathrm{~V}\right.$, $E_{1}=-1.6 \mathrm{~V}, f=0.1 \mathrm{kHz} ; t=1 \mathrm{~min}$ ) (Fig. 1a) show two main pairs of current peaks located at about 1.0 and $1.5 \mathrm{~V}$ which resemble those found for polycrystalline $(p c)$ Co and electroless-prepared Co electrodes in alkaline solution. These peaks were assigned to the $\mathrm{Co}(\mathrm{OH})_{2} / \mathrm{Co}_{3} \mathrm{O}_{4}$ and the $\mathrm{Co}(\mathrm{OH})_{2} / \mathrm{CoOOH}$ redox reactions[16-19]. A slight voltammetric charge increase yielding $R=4$ can be observed in going from type I to type II $\mathrm{Co}-\mathrm{P}$ we (Fig. 1a).

For $\mathrm{Co}-\mathrm{Ni}-\mathrm{P}$ amorphous alloys, the voltammograms run at $0.1 \mathrm{~V} \mathrm{~s}^{-1}$ between 0.30 and $1.55 \mathrm{~V}$ for type I we and type II we are depicted in Fig. 1b. The voltammogram of type I we shows two anodic peaks located at about 1.05 and $1.35 \mathrm{~V}$ and a cathodic peak at $1.35 \mathrm{~V}$, which were assigned to the $\mathrm{Ni}(\mathrm{II}) / \mathrm{Ni}$ (III) and $\mathrm{Co}(\mathrm{III}) / \mathrm{Co}(\mathrm{IV})$ redox reactions[20-27]. Otherwise, the voltammogram of type II we prepared by SWPR treatment $\left(E_{\mathrm{u}}=1.0 \mathrm{~V}\right.$, $E_{l}=-1.7 \mathrm{~V}, f=0.1 \mathrm{kHz}, t=1 \mathrm{~min}$ ), shows only one pair of current peaks which resembles that reported for either Co-Ni and Co-spinels[20, 23, 26, 27] or galvanostatically deposited $\mathrm{Co}-\mathrm{Ni}-\mathrm{P}$ alloys $[28,29]$. On the other hand, the increase in voltammetric charge for the type II $\mathrm{Co}-\mathrm{Ni}-\mathrm{P}$ amorphous alloy $(R=24)$ (Fig. 1b) is greater than that for the type II Co-P amorphous alloy (Fig. 1a).

SWPR parameters were systematically changed in order to achieve the largest value of $R$. For Co-P amorphous alloys, the optimal value $E_{\mathrm{u}}=1.6 \mathrm{~V}$ was approached by setting $f=0.1 \mathrm{kHz}$ and $E_{1}$ exceeding the hydrogen evolution reaction (her) threshold potential (Fig. 2a). Correspondingly, by setting $E_{\mathrm{u}}=$ $1.6 \mathrm{~V}$ and $f=0.1 \mathrm{kHz}$, the greatest value of $R$ was attained for $E_{1}=-1.6 \mathrm{~V}$ (Fig. 2b). Likewise, by

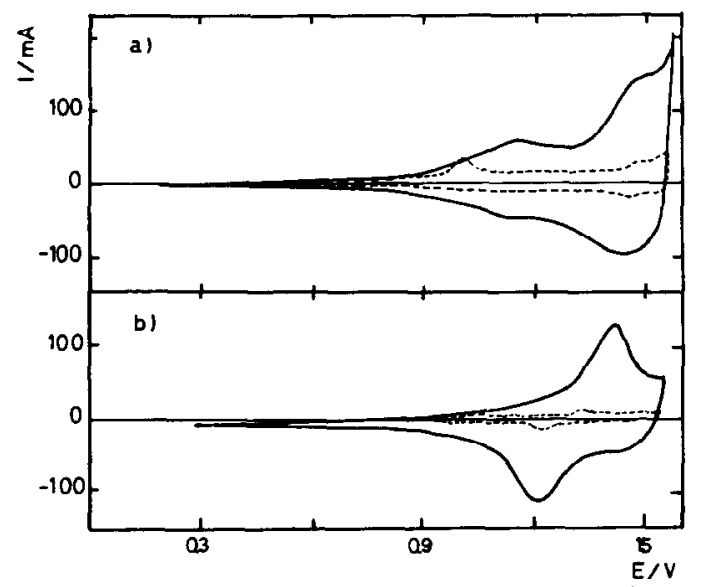

Fig. 1. Stabilized voltammograms at $0.1 \mathrm{~V} \mathrm{~s}^{-1}$ for untreated (type I) (-..-) and oxide coated (type II) (-) $\mathrm{Co}-\mathrm{P}$ (a) and $\mathrm{Co}-\mathrm{P}-\mathrm{Ni}$ (b) electrodes in $1 \mathrm{M} \mathrm{NaOH} ; 30^{\circ} \mathrm{C}$.

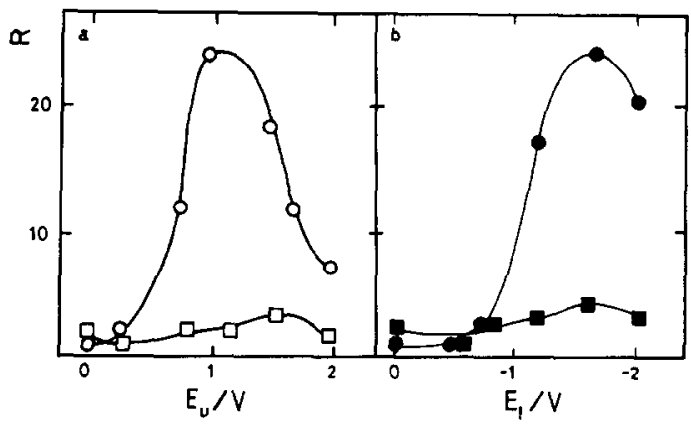

Fig. 2. Dependence of $R$ on $E_{\mathrm{u}}$ (a) and $R$ on $E_{1}$ (b) for Co-P and Co-Ni P electrodes after 1 min SWPR treatment at $f=0.1 \mathrm{kHz}$ : $(\square)$ Co-P alloy $\left(E_{1}=-1.0 \mathrm{~V}\right)$; (O) Co-Ni-P alloy $\left(E_{1}=-1.0 \mathrm{~V}\right)$; (G) Co-P alloy $\left(E_{u}=1.6 \mathrm{~V}\right)$;

(O) Co-Ni-P alloy $\left(E_{u}=1.0 \mathrm{~V}\right)$. Data taken from voltammograms run at $0.1 \mathrm{~V} \mathrm{~s}^{-1}$ in $1 \mathrm{M} \mathrm{NaOH} ; 30^{\circ} \mathrm{C}$.

setting $E_{\mathrm{u}}=1.6 \mathrm{~V}$ and $E_{1}=-1.6 \mathrm{~V}$, the optimal value $f=0.1 \mathrm{kHz}$ was found (Fig. 3). Analogously, for Co-Ni-P amorphous alloys the optimal SWPR parameters were $E_{\mathrm{u}}=1.0 \mathrm{~V}, E_{1}=-1.7 \mathrm{~V}$ and $f=0.1 \mathrm{kHz}$ (Figs 2 and 3 ).

Ir spectra of type I Co-P amorphous alloy powders show no absorption bands in the 4000 $400 \mathrm{~cm}^{-1}$ range (Fig. 4a). Otherwise, ir spectra of airdried powdered oxide coatings display a broad absorption band at $c a .580 \mathrm{~cm}^{-1}$ (Fig. 4b), whereas for thermally-treated powdered oxide coatings samples bands at 560 and $660 \mathrm{~cm}^{-1}$ (Fig. 4c and d), which are typical of chemically prepared $\mathrm{Co}_{3} \mathrm{O}_{4}$ spinel[30,31], are observed. On the other hand, for type I Co-Ni-P amorphous alloy powders, featureless ir spectra are recorded (Fig. 4a). The spectra of air-dried powdered metal oxide coatings show an absorption band at ca. $580 \mathrm{~cm}^{-1}$ (Fig. 4b), which is similar to that reported for both hydrous $\mathrm{Ni}$ and $\mathrm{Co}$ oxide layers produced on $p c \mathrm{Ni}$ and $p c$ Co electrodes by the same procedure $[10,11]$. ir spectra of thermally treated powdered oxide coatings exhibit absorption bands at 560 and $660 \mathrm{~cm}^{-1}$ (Fig. 4c and d), which can be assigned to a Co-spinel structure [30, 31] as the same spectrum can be obtained from a chemically prepared $\mathrm{Co}_{3} \mathrm{O}_{4}$ spinel (Fig. 4). It should be noted that the main absorption bands of chemically prepared $\mathrm{NiCo}_{2} \mathrm{O}_{4}$ spinel and

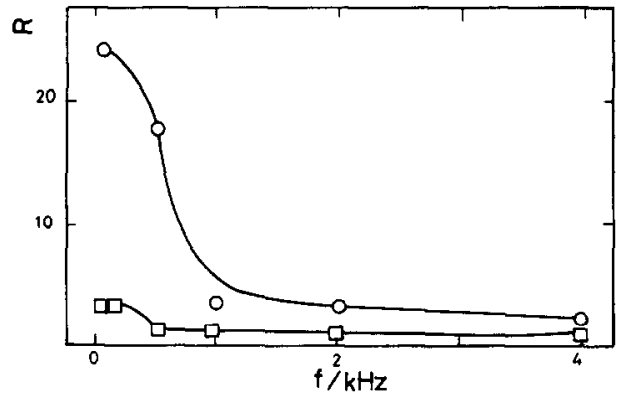

Fig. 3. Dependence of $R$ on $f$ for Co-P and Co-Ni-P electrodes after $1 \mathrm{~min}$ SWPR treatment: $(\square)$ Co-P alloy $\left(E_{1}=\right.$ $\left.-1.6 \mathrm{~V} ; E_{\mathrm{u}}=1.6 \mathrm{~V}\right) ;(0) \mathrm{Co}-\mathrm{Ni}-\mathrm{P}$ alloy $\left(E_{1}=-1.7 \mathrm{~V}\right.$; $E_{\mathrm{u}}=1.0 \mathrm{~V}$ ). Data are taken from voltammograms run at $0.1 \mathrm{~V} \mathrm{~s}^{-1}$ in $1 \mathrm{M} \mathrm{NaOH} ; 30^{\circ} \mathrm{C}$. 


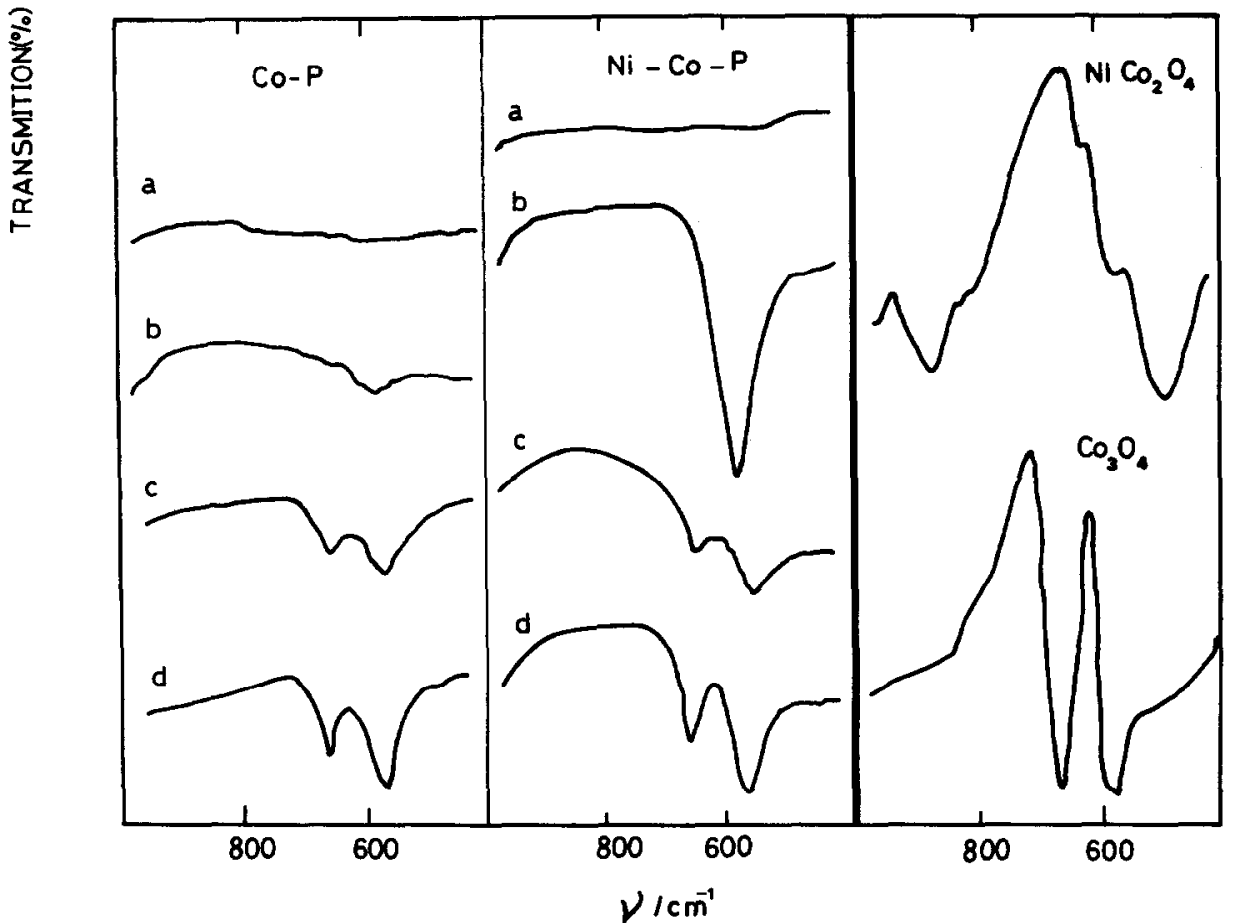

Fig. 4. Ir spectra of oxide powders resulting from untreated and SWPR treated Co-P and Co-Ni-P electrodes; chemically prepared $\mathrm{Co}-\mathrm{Ni}$ and Co-spinels: (a) untreated samples; (b) air-dried powdered oxide coatings; (c) sample prepared as (b) and treated at $380^{\circ} \mathrm{C}$ for $2 \mathrm{~h}$ under $\mathrm{N}_{2}$; (d) sample prepared as

(b) and treated at $380^{\circ} \mathrm{C}$ for $21 \mathrm{~h}$ under $\mathrm{N}_{2}$.

$\mathrm{Ni}$ oxide coatings produced by SWPR treatment[32], are expected at 480 and $560 \mathrm{~cm}^{-1}$ (Fig. 4) and at 420 and $650 \mathrm{~cm}^{-1}$, respectively.

Polarization curves run at $10^{-4} \mathrm{~V} \mathrm{~s}^{-1}$ in the oer potential range were plotted as $E$ vs. $\log j$ (Fig. 5). Tafel regions with slopes approaching $0.06 \mathrm{~V}_{\text {decade }}^{-1}$ are obtained for both type I and type II Co-P we. Otherwise, similar current density values at constant potential are obtained from both type I and type II $\mathrm{Co}-\mathrm{P}$ we.

For $\mathrm{Co}-\mathrm{Ni}-\mathrm{P}$ electrodes, the oer polarization curves fit Tafel lines with slopes of $0.04 \mathrm{~V}_{\text {decade }}{ }^{-1}$ and $0.06 \mathrm{Vdecade}^{-1}$ for type I and type II we, respectively. Otherwise, the current density values at constant potential for both type I and type III Co-Ni-P we are also lower than those for type II we.

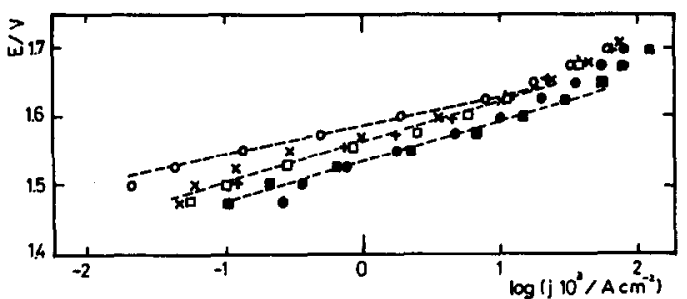

Fig. 5. Tafel plots derived from oer polarization curves for $\mathrm{Co}-\mathrm{P}$ and $\mathrm{Co}-\mathrm{Ni}-\mathrm{P}$ electrodes in $1 \mathrm{M} \mathrm{NaOH} ; 30^{\circ} \mathrm{C}$. Untreated (type I) ( $\square$ ) $\mathrm{Co}-\mathrm{P}$ and $(\mathrm{O}) \mathrm{Co}-\mathrm{Ni}-\mathrm{P}$ alloys. Oxide coated (I) Co-P and (O) Co-Ni-P alloys. Oxide coated $(+)$ Co-P and $(x)$ Co-Ni-P alloys, after thermal treatment at $380^{\circ} \mathrm{C}$ during $21 \mathrm{~h}$ (type III).

\section{DISCUSSION}

\subsection{Characteristics of oxide coatings}

The comparison of ir spectra of SWPR treated amorphous alloys to those of chemically prepared $\mathrm{Co}_{3} \mathrm{O}_{4}$ and $\mathrm{NiCO}_{2} \mathrm{O}_{4}$ spinels demonstrates that a hydrous oxide coating which acts as a precursor of a Co-spinel structure is formed on electrolessdeposited $\mathrm{Co}-\mathrm{P}$ and $\mathrm{Co}-\mathrm{Ni}-\mathrm{P}$ amorphous alloys after the SWPR treatment, yielding a true spinel structure by thermal treatment at $380^{\circ} \mathrm{C}$.

Likewise, after potential cycling, galvanostatically deposited $\mathrm{Co}-\mathrm{Ni}-\mathrm{P}$ amorphous alloys, exhibit the formation of only $\mathrm{Co}(\mathrm{OH}), \beta-\mathrm{CoO}(\mathrm{OH})_{2}$ and $\alpha$-Co phases as revealed by $\mathrm{X}$-ray diffraction patterns, independently of the $\mathrm{Co} / \mathrm{Ni}$ ratio in the alloy $[28,29]$.

The formation of spinel-type structures is also consistent with the first voltammograms resulting from type II Co-P and Co-Ni-P alloys which always show the same features as those obtained from SWPR treated $p c \operatorname{Co}[11]$. Furthermore, the stabilized voltammograms for type III we exhibit a conjugated pair of peaks which resembles that reported for Co-spinels[19-21, 23, 27]. Therefore, for both $\mathrm{Co}-\mathrm{P}$ and $\mathrm{Co}-\mathrm{Ni}-\mathrm{P}$ amorphous alloys it appears that the average composition of the oxide coating is dominated by $\mathrm{Co}$ oxides.

\subsection{Optimal SWPR conditions for oxide coating formation}

Type II we with the largest $R$ values are produced by SWPR treatment with the following characteristics $1.6 \mathrm{~V}>E_{\mathrm{u}}>1.0 \mathrm{~V} ; \quad E_{1} c a .-1.6 \mathrm{~V}$ and 
$f=0.1 \mathrm{kHz}$, the composition of these coatings being dominated by $\mathrm{Co}$ species. This result is consistent with the voltammetric behaviour of $p c \mathrm{Ni}$ and $p c \mathrm{Co}$ in alkaline solution $[17,33]$. Thus $p c \mathrm{Ni}$ can be easily electro-oxidized to $\mathrm{Ni}(\mathrm{II})$ and $\mathrm{Ni}$ (III) oxi-hydroxide species within the $E_{\mathrm{u}}$ optimal range, although these species are hardly electroreduced to $\mathrm{Ni}(0)$ within the $E_{1}$ optimal range. On the other hand, the voltammetric behaviour of $p c$ Co in alkaline solution covering the $E_{1}$ and $E_{\mathrm{u}}$ optimal range shows at least two reversible systems comprising only $\mathrm{Co}(0)$ and $\mathrm{Co}$ (II) oxidation states[17].

The electrochemical behaviour of $p c \mathrm{Co}$ and $p c \mathrm{Ni}$ under potential cycling conditions can explain the trend of Co electrode reactions to follow the potential routine yielding a $\mathrm{Co}(\mathrm{OH})_{2}$ enriched layer for $E_{1}$ values located in the her potential range. The low $f$ value required for the $\mathrm{Co}(\mathrm{OH})_{2}$ accumulation is presumably conditioned by the Co electrode kinetics $[11,12]$. The formation of a relatively large amount of soluble $\mathrm{Co}^{2+}$ species and the precipitation and accumulation of $\mathrm{Co}(\mathrm{OH})_{2}$ at $E_{1}$, are favoured at low $f$ values.

\subsection{Electrocatalytic influence of oxide coatings on} oer

The oer Tafel slope $\left(b_{\mathrm{T}}\right)$ for type II $\mathrm{Co}-\mathrm{Ni}-\mathrm{P}$ we changes from 0.04 to $0.06 \mathrm{~V} \mathrm{decade}^{-1}$, ie to a typical Tafel slope for $\mathrm{Co}_{3} \mathrm{O}_{4}$ spinel in the same solution[21, 31].

This change in $b_{\mathrm{T}}$ can be due either to a change in the surface oxide layer composition or a change in the active sites characteristics caused by surface interactions. Otherwise, the change in $b_{\mathrm{T}}$ reported for crystalline $\mathrm{Ni}-\mathrm{Co}$ alloys in alkaline solutions has also been explained by the different nature of surface oxides[21]. Thus, a $\mathrm{NiCo}_{2} \mathrm{O}_{4}$-spinel-like voltammetric behaviour is attained after potential cycling at $0.02 \mathrm{~V} \mathrm{~s}^{-1}$ and, under these conditions, $b_{\mathrm{T}}=$ $0.04 \mathrm{~V}$ decade $^{-1}$ has been reported, whereas preanodization at $1.8 \mathrm{~V}$ vs. rhe led to a $\mathrm{Co}_{3} \mathrm{O}_{4}$-type electrode for which $b_{\mathrm{T}}=0.06 \mathrm{~V}$ decade ${ }^{-1}[21]$.

As recently reported by Burke et al.[7, 9, 34], oxide layers produced on several metals by potential cycling improve the oer catalytic activity. This enhancement has been related to the hydrous structure of the oxide coatings produced by the potential routine treatment. Accordingly, hydrous oxide coatings are also produced by SWPR treatment of amorphous alloys. Furthermore, type II we can be described as spinel-type structures which exhibit a relatively large active surface area for the oer. In addition, type II we exhibit an oer catalytic activity higher than that of type III we. The lower catalytic activity of type III we can be attributed to the decrease in active surface area due to the dehydration caused by thermal treatment.

On the other hand, type II $\mathrm{Co}-\mathrm{P}$ and $\mathrm{Co}-\mathrm{Ni}-\mathrm{P}$ we present similar current density values at constant potential despite the considerable difference in the corresponding values of $R$. Thus, it might be concluded that for both electrodes nearly the same active surface area is involved. The value of $R$ is probably related to the total amount of oxide coating instead of the true active surface area for the oer. A comparable observation was made by
Trasatti[19] about the meaning of roughness factor values as determined from voltammetry and capacitive current densities. Accordingly, the oer on type II we takes place predominantly on the external surface of oxide coatings, as earlier reported $[35,36]$.

\section{CONCLUSIONS}

Hydrous oxide films can be grown on electrolessprepared $\mathrm{Co}-\mathrm{P}$ and $\mathrm{Co}-\mathrm{Ni}-\mathrm{P}$ amorphous alloys in alkaline solution by applying SWPR treatments under appropriate conditions.

For both amorphous alloys the hydrous oxide coatings are mainly formed by $\mathrm{Co}$ oxide species. These oxide coatings behave as precursors of $\mathrm{Co}-$ spinel structures. True spinel structures are produced by thermal treatment of hydrous oxide coated electrodes.

Both hydrous oxide coated amorphous alloys behave more active for the oer than the corresponding untreated and thermally treated oxide coated electrodes.

Acknowledgements-This research project was supported by the Consejo Nacional de Investigaciones Científicas y Técnicas of Argentina and the Regional Program for the Scientific and Technological Development of the Organization of American States. T. Kessler and R. C. V. Piatti are members of the Comisión de Investigaciones Científicas de la Provincia de Buenos Aires.

\section{REFERENCES}

1. G. Kreysa and B. Hakansson, J. electroanal. Chem. 201, 61 (1986).

2. A. Baiker, Faraday Discuss. Chem. Soc. 87, 239 (1989).

3. G. A. Tsirlina, O. A. Petrii and N. S. Kopylova, Elektrokhimiya 26, 1059 (1990).

4. F. Pearlstein, in Modern Electroplating (Edited by F. A. Lowenheim). John Wiley, New York (1974).

5. M. Schlesinger, in Electroless Deposition on Metals and Alloys, Proceedings, Vol. 88-12, p. 93. The Electrochemical Society, Pennington, New York (1988).

6. J. J. Podestá, R. C. V. Piatti, A. J. Arvia, P. Edkunge, K. Jüttner and G. Kreysa, Int. J. Hyd. Energy 17, 9 (1992)

7. L. D. Burke and O. J. Murphy, J. electroanal. Chem. 109, $373(1980)$.

8. A. C. Chialvo, W. E. Triaca and A. J. Arvia, J. electroanal. Chem. 146, 93 (1983).

9. L. D. Burke and M. E. Lyons, in Modern Aspects of Electrochemistry, Vol. 18 (Edited by J. O'M. Bockris, B. E. Conway and R. E. White), p. 169. Plenum Press, New York (1986).

10. A. Visintin, A. C. Chialvo, W. E. Triaca and A. J. Arvia, J. electroanal. Chem. 225, 227 (1987).

11. T. Kessler, M. R. G. de Chialvo, A. Visintin, W. E. Triaca and A. J. Arvia, J. electroanal. Chem. 261, 315 (1989).

12. T. Kessler, W. E. Triaca and A. J. Arvia, J. appl. Electrochem. 23, 655 (1993).

13. T. Kessler, W. E. Triaca and A. J. Arvia, J. appl. Electrochem., 24, 310 (1994).

14. D. F. Untereker and S. Bruckenstein, J. electrochem. Soc. 121, 360 (1974).

15. C. L. Perdriel, W. E. Triaca and A. J. Arvia, J. electroanal. Chem. 205, 279 (1986). 
16. W. K. Behl and J. E. Toni, J. electroanal. Chem. 31, 63 (1971).

17. H. Gomez Meier, J. R. Vilche and A. J. Arvia, J. electroanal. Chem. 138, 367 (1982).

18. T. R. Yayaraman, V. K. Venkatesan and H. V. K. Udupa, Electrochim. Acta 20, 209 (1975).

19. R. Boggio, A. Carugati and S. Trasatti, J. appl. Electrochem. 17, 828 (1987).

20. M. Hamdani, J. F. Koenig and P. Chartier, J. appl. Electrochem. 18, 568 (1988).

21. J. Haenen, W. Visscher and E. Barendrecht, Electrochim. Acta 11, 1541 (1966).

22. M. R. G. de Chialvo and A. C. Chialvo, Electrochim. Acta 36, 963 (1991).

23. J. Haenen, W. Visscher and E. Barendrecht, J. electroanal. Chem. 208, 273 (1986).

24. K. K. Lian and V. I. Birss, J. electrochem. Soc. 138, 2877 (1991).

25. K. Lian, S. J. Thorpe and D. W. Kirk, Electrochim. Acta 37, 2029 (1992).

26. P. Rasiyah, A. C. C. Tseung and D. B. Hibbert, J. electrochem. Soc. 129, 1724 (1982).
27. D. B. Hibbert and Ch. R. Churchill, J. Chem. Soc. Faraday Trans. I, 80, 1965 (1984).

28. A. Budniok and J. Kupka, Electrochim. Acta 34, 871 (1989).

29. J. Kupka and A. Budniok, J. appl. Electrochem. 20, 106 (1990).

30. J. Preudhomme and P. Tarte, Spectrochim. Acta 27A, 1817 (1971).

31. M. R. Tarasevich and B. N. Efremov, in Electrodes of Conductive Metallic Oxides (Edited by S. Trasatti), Part A, p. 221. Elsevier, Amsterdam (1980).

32. A. Visintin, W. E. Triaca and A. J. Arvia, in preparation.

33. R. S. Schrebler Guzmán, J. R. Vilche and A. J. Arvia, J. electrochem. Soc. 125, 1578 (1978).

34. L. D. Burke and E. J. M. O'Sullivan, J. electroanal. Chem. 117, 155 (1981).

35. H. Wendt and V. Plzak, Electrochim. Acta 28, 27 (1983).

36. S. P. Jiang and A. C. C. Tseung, J. electrochem. Soc. 138, 1216 (1991). 